\title{
Top-Down and Bottom-Up Interactions Influence Fledging Success at North America's Largest Colony of Caspian Terns (Hydroprogne caspia)
}

\author{
Stefanie Collar ${ }^{1}$ (D) - Daniel D. Roby ${ }^{2}$ Donald E. Lyons ${ }^{1}$
}

Received: 1 February 2016/Revised: 9 March 2017 / Accepted: 13 March 2017 /Published online: 25 May 2017

(C) The Author(s) 2017. This article is an open access publication

\begin{abstract}
Our study investigated the influence of bottom-up and top-down drivers on the declining fledging success at a once thriving breeding colony of Caspian terns (Hydroprogne caspia). Situated at the mouth of the Columbia River, OR, East Sand Island (ESI) is home to the largest Caspian tern breeding colony in North America. Since 2001, the decline in fledging success of Caspian terns at ESI has been associated with a significant increase in average river discharge during May and June. During the years 2001-2011, the abundance of forage fish available to terns in the estuary was inversely related to river discharge. This relationship also apparently affected the reliance of nest predators on the tern colony as a food source, resulting in increased disturbance and decreased fledging success at the tern colony in years of higher river discharge. There was a significant longitudinal increase in disturbance rates by bald eagles (Haliaeetus leucocephalus) during June for terns nesting at the ESI colony, and eagle disturbance rates were positively associated with May river discharge. We also found a significant increase in kleptoparasitism rates of terns by hybrid glaucous-winged/
\end{abstract}

Communicated by James Lovvorn

Stefanie Collar

stefanie.collar@gmail.com

1 Oregon Cooperative Fish and Wildlife Research Unit, Department of Fisheries and Wildlife, Oregon State University, 104 Nash Hall, Corvallis, OR 97331, USA

2 US Geological Survey - Oregon Cooperative Fish and Wildlife Research Unit, Department of Fisheries and Wildlife, Oregon State University, 104 Nash Hall, Corvallis, OR 97331, USA western gulls (Larus glaucescens x Larus occidentalis) since 2001, and Caspian tern fledging success at ESI decreased with increasing average annual rates of gull kleptoparasitism. Our results support the hypothesis that the decline in Caspian tern fledging success at this large estuarine colony was primarily driven by the interaction of bottom-up and top-down factors, influencing tern fledging success through the food supply and triggering potential predators to identify the tern breeding colony as an alternative source of prey.

Keywords Columbia River estuary $\cdot$ Caspian tern $\cdot$ Trophic interactions · Bottom-up · Top-down · Synergistic predation

\section{Introduction}

In the decades since the top-down versus bottom-up debate began in community ecology, focus has shifted to a more nuanced view: that the unique interactions between predators and producers shape individual ecological communities (Hunt and McKinnell 2006; Suryan et al. 2006; Gripenberg and Roslin 2007). Nesting success at seabird breeding colonies involves a precarious balance between prey availability, suitable nesting habitat, avoidance of predators, and favorable weather. For this reason, seabird breeding colonies tend to reflect the nuanced interplay of top-down and bottom-up constraints (Suryan et al. 2006). Munch et al. (2005) posited that bottom-up forcing should be most obvious in its regulation of adult recruitment to the breeding population and that topdown regulation would be reflected in high egg and chick mortality. Given the complexity of the interactions at a large breeding colony, however, treating bottom-up and top-down 
factors as competing alternative hypotheses to explain nesting success may not be appropriate.

Prey resources utilized by a seabird colony are often also resources for other avian residents, species that can be potential predators on seabird nests or breeding adults. Some species of gull (Larus spp.) that may primarily exploit piscine prey can also be voracious egg and chick predators, and many raptors will opportunistically take adult colonial seabirds or their eggs and chicks, especially if alternative food sources or prey are scarce (Isaacs and Anthony 2011; Harvey et al. 2012). It is in complicated systems such as these that we can potentially see the "chutes and ladders" of a dynamic food web proposed by Hunter and Price (1992). Rather than the simplistic view of two prospective hypotheses in conflict, Hunter and Price (1992) emphasized the importance of food web connections that are not restricted by trophic level or direction. Acknowledging the inherent dynamism of seabird colony ecology allows for a more complete understanding of trophic interactions. In the present study, we sought to understand how top-down and bottom-up forces interacted in this system and influenced the fledging success of Caspian terns (Hydroprogne caspia) at East Sand Island in the Columbia River estuary, the largest breeding colony for the species in North America.

Although the number of breeding pairs using the East Sand Island Caspian tern colony remained at $~ 9000$, fledging success declined from 1.39 young fledged/pair in 2001 to 0.05 and 0.0 young fledged/pair in 2010 and 2011, respectively. A potential explanation for declining fledging success at the East Sand Island Caspian tern colony is top-down factors, such as increasing predation pressure on breeding adults and their eggs and chicks. An alternative explanation is bottom-up factors that influence food availability to adults and chicks. The prey base for the East Sand Island colony, located near the mouth of the Columbia River, is influenced by both river discharge and tidal fluctuations. Estuaries are dynamic ecosystems of great biological and hydrological complexity (Weitkamp et al. 2012), and bottom-up factors can influence the success of organisms throughout the food web, effectively turning bottom-up limitations on tern nesting success into topdown controls. Consequently, it is imperative to consider the interactions between bottom-up and top-down forcing as constraints for seabird nesting (Suryan et al. 2006).

Our study investigated the potential drivers for the declining fledging success at this once thriving colony of Caspian terns. We attempted to identify causal factors behind the decline in fledging success during the decade since the colony became established in 1999. Our primary objective was to identify relationships between colony attributes and environmental factors and to understand how these elements might be linked. We explored decadal patterns evident in these relationships and attempted to explain which factors limited fledging success, with particular interest in the unprecedented low fledging success of the 2010 and 2011 breeding seasons.

\section{Methods}

\section{Study Area}

East Sand Island (ESI) $\left(46^{\circ} 15^{\prime} 45^{\prime \prime} \mathrm{N}, 123^{\circ} 57^{\prime} 45^{\prime \prime} \mathrm{W}\right)$, in the Columbia River estuary near the mouth of the Columbia River, has been the site of a perennial Caspian tern breeding colony since 1999 . This colony was established using nesting habitat enhancement and social attraction (decoys and audio playback of vocalizations). ESI is home to the second largest breeding colony of western gulls (Larus occidentalis) and hybrid glaucous-winged/western gulls (Larus glaucescens $\mathrm{x}$ L. occidentalis) on the West Coast of the USA (Collis et al. 2002). Annual maintenance of early seral stage nesting habitat at the colony site ensured that suitable nesting habitat for Caspian terns persisted on ESI.

\section{Fledging Success Data}

Aerial photo census methods used in this study follow Collis et al. (2002). We estimated the number of breeding pairs using aerial photographs of the colony taken at the time of peak incubation. We estimated average annual fledging success of Caspian terns nesting at the ESI colony from 2000 to 2011 using aerial photographs of the colony and simultaneous counts from the ground of the number of adults and chicks on sample plots within the colony. An average of two direct counts from the photos of all terns (adults and juveniles) on the colony was corrected using simultaneous counts from the blinds of adults and fledglings on sample plots. Sample plots were $6 \times 6 \mathrm{~m}$, placed to represent the edge and interior of the colony to account for density differences, and observable from one of three observation blinds located on the colony periphery. This census took place after peak hatch on the colony had occurred. We divided the estimated total number of fledglings produced by the estimated number of breeding pairs to estimate colony fledging success (the average number of young fledged per breeding pair).

\section{Climate Data}

\section{River Discharge}

Data on river discharge for the Columbia River were downloaded from the US Geological Survey website (http:// waterdata.usgs.gov) for river km 86 (site number 14246900), which is downstream of the confluence of all major tributaries to the Columbia River. We compiled average monthly river discharges (thousands of cubic feet per second; $k c f s$ ) for the months of April, May, and June during 2001-2011, which includes the period of Caspian tern nest initiation, incubation, and early chick rearing at our study site. 


\section{Diet Data}

\section{Diet Composition}

We conducted twice daily observations of Caspian terns returning to the breeding colony with bill-load fish, in all weather, from nest initiation until after peak fledge. Twenty-five bill-load fish were visually identified during each session, and the sessions took place at high and low tides each day to control for potential effects of tide stage and time of day on tern diet composition.

We calculated the average taxonomic composition of Caspian tern diets for each breeding season, identifying to family Osmeridae, Embiotocidae, Clupeidae (including Pacific herring [Clupea pallasi], Pacific sardine [Sardinops sagax], and American shad [Alosa sapidissima]), Engraulidae, and Salmonidae (Oncorhynchus spp., primarily steelhead [Oncorhynchus mykiss], coho [Oncorhynchus kisutch], and chinook [Oncorhynchus tshawytscha]) (Collis et al. 2002). The species composition of fish in Caspian tern bill loads (\% of identifiable bill loads) was determined visually at the colony during each 2 -week period of the breeding season, and the overall composition of the diet during each breeding season was based on the average of these 2 -week percentages. We used the annual taxonomic composition of the Caspian tern diet for each year during 2001-2011 in the analysis (www.birdresearchnw. org).

\section{Prey Availability}

Prey availability data were obtained from purse seining conducted by the National Oceanic and Atmospheric Administration (NOAA). Trawls occurred during daylight hours every 2 weeks from mid-April to late June or early July during 2007-2011 at two stations in the lower Columbia River estuary. Sampling was conducted during flood tides with a fine mesh purse seine $(10.6 \mathrm{~m}$ deep, $155 \mathrm{~m}$ long, stretched mesh opening of $1.7 \mathrm{~cm}$ ) set at depths of between 7 and $10 \mathrm{~m}$ in order to effectively sample the entire water column. Catch per unit of effort (CPUE) was recorded as total number of individuals $/ 1000 \mathrm{~m}^{2}$ round haul and as percent of total abundance of each species collected (see Weitkamp et al. 2012). We were given access to, and analyzed, data spanning 2007-2011, 1 year more than the data available in the Weitkamp et al. (2012) publication. We eliminated three-spined stickleback (Gasterosteus aculeatus) from the reported CPUE before analysis to better characterize the abundance of prey representative of tern diets.

\section{Predator Data}

\section{Eagle Disturbance}

Any disturbance that resulted in at least $10 \%$ of the adult terns on the breeding colony taking flight during a scheduled billload identification observation period was recorded by the observer and entered into a database. Each record included the time of the disturbance, the percent of adults on colony that were flushed, the cause of the disturbance (if discernible), and the number of seconds elapsed from the start of the disturbance until $50 \%$ of flushed terns had re-landed on the colony.

We reconstructed monthly rates of bald eagle (Haliaeetus leucocephalus) disturbance using data from 2004 to 2011. To estimate eagle disturbance rates for each month, the number of disturbances to the tern colony by eagles recorded during a month was divided by the number of hours of bill-load observations recorded in that month.

\section{Counts of Breeding Gulls}

Aerial photo census methods used in this study follow Collis et al. (2002). We estimated the number of individuals directly from aerial photographs of the colony taken coincident with peak incubation, when maximum colony attendance by breeding birds was assumed. Direct counts of the number of individuals on colony were used as indices to the number of nesting pairs.

\section{Gull Predation Rates}

During focused observations of gull predation plots throughout the colony, we observed and recorded all gull predation events for a known time period. Each year, we randomly selected areas of the colony for plots that encompassed approximately 50 contiguous nests. These plots changed as nest density fluctuated over the breeding season and included both the edge and interior of the colony. We recorded date, start and end time, blind location, all colony disturbance events, observer, and notes and recorded the number of eggs or chicks taken, the status of the nest, and the depredating species for every predation event. We performed $3 \mathrm{~h}$ of gull predation rate observations each week in 1-h observation bouts.

We measured rates of gull predation on Caspian tern nest contents by dividing the total number of gull predation events recorded in a month by the total number of hours spent recording gull predation events during that month. We pooled observations from each blind to estimate each monthly rate. We collected data on gull predation rates during 2007-2011; however, rates of gull predation could not be fully captured using this methodology during the 2011 breeding season. Intense gull nest predation was closely associated with acute 
colony disturbance events caused by bald eagles during the 2011 breeding season, and the nature of gull predation at the colony in that year was highly episodic.

\section{Kleptoparasitism by Gulls}

During the twice daily observation periods for diet composition, we assigned each tern bill-load observation to one of several final fates: (1) eaten by the individual transporting the bill load, (2) fed to the potential mate, (3) fed to a tern chick, (4) stolen by a conspecific, or (5) kleptoparasitized by a gull. We calculated gull kleptoparasitism rates by dividing all kleptoparasitized fish by the total number of fish with assigned final fates. The kleptoparasitism rates used in the analysis were the total rates for each breeding season during 20012011.

\section{Data Analyses}

We created linear regression models corresponding to a priori biologically relevant hypotheses. We used Akaike's information criterion corrected for small sample sizes (AICc) to identify the most parsimonious model supported by the data. Because of high correlation between some explanatory variables, and the small sample size for the response variable ( $n$ $=11$ years), all interactions could not be included in prospective models. We identified potential correlations between explanatory variables with the Pearson's correlation function in $\mathrm{R}$, and variables with correlations significant at the $\alpha=0.05$ level were not included together in the potential model selection sets. Values were calculated for $\triangle \mathrm{AICc}$ for all potential models, and the top five models are presented here for comparison. All analyses were performed with the R statistical packages bblme, Hmisc, and Mass (R Development Core Team 2011). Any use of trade, firm, or product names is for descriptive purposes only and does not imply endorsement by the US government.

\section{Results}

\section{Fledging Success}

From 2001 to 2011, the fledging success (number of young fledged/breeding pair) of Caspian terns at the ESI colony declined significantly $\left(R^{2}=0.82, \mathrm{df}=9, P<0.001\right.$; Fig. 1$)$. Fledging success declined from a high of 1.39 young fledged/breeding pair in 2001 to 0 young fledged/breeding pair in 2011. The failure of any breeding pairs to fledge young in 2011 was unprecedented at this colony, since monitoring began in 2001.

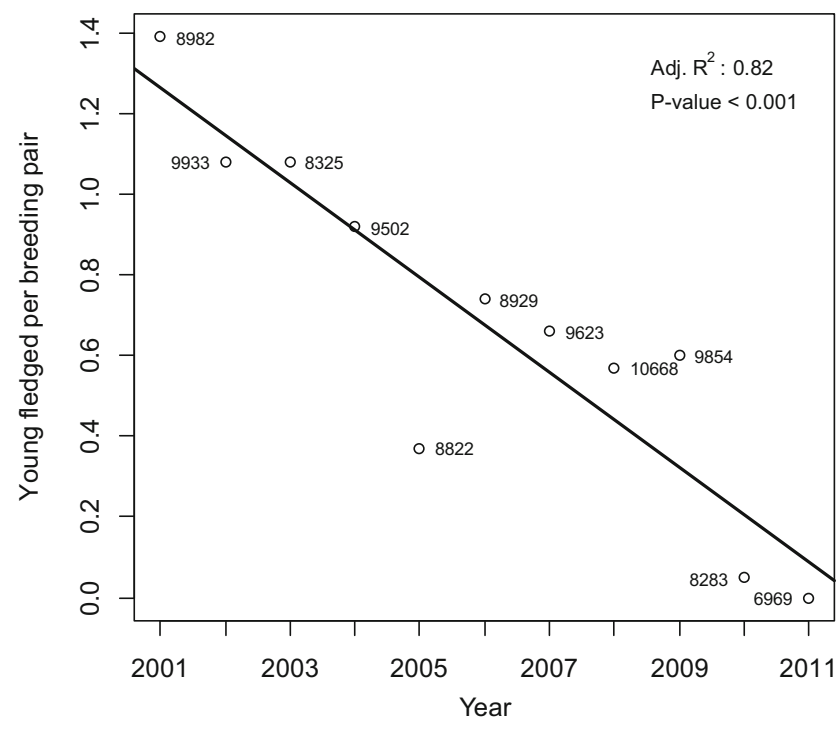

Fig. 1 Annual fledging success (average number of young fledged per breeding pair) of the Caspian tern breeding colony on East Sand Island in the Columbia River estuary as a function of year during 2001-2011 $\left(R^{2}=0.82, \mathrm{df}=9, P<0.001\right)$. Data point labels indicate the size of the breeding colony (number of breeding pairs) at East Sand Island in that year

\section{Climate}

\section{River Volume}

Average May flow volume of the Columbia River increased significantly $\left(R^{2}=0.56, \mathrm{df}=9, P=0.01\right)$ from 2001 to 2011 . For May river discharge, there was a significant negative relationship with fledging success at the ESI Caspian tern colony during the years 2001-2011 $\left(R^{2}=0.43, \mathrm{df}=9, P=0.03\right)$. Average river discharge of the Columbia River for June also increased significantly during 2001-2011 $\left(R^{2}=0.56, \mathrm{df}=9\right.$, $P=0.01)$. The negative correlation between June river discharge and fledging success at the Caspian tern colony was significant for the years 2001-2011 $\left(R^{2}=0.49, \mathrm{df}=9\right.$, $P=0.02)$. The May and June combined average river discharge (kcfs) during 2001-2011 was also negatively correlated with fledging success for Caspian terns at ESI $\left(R^{2}=0.51\right.$, $\mathrm{df}=9, P=0.01$; Fig. 2). In both May and June of 2011, the year when the ESI Caspian tern colony failed to produce any fledglings, average river discharge was more than $100 \mathrm{kcfs}$ greater than the next highest river discharge for those 2 months during the 11-year study period.

Based on the relationship between May river discharge and fledging success during 2001-2009, the predicted value for colony fledging success in 2010 was 0.97 fledglings/breeding pair, while the observed value was 0.05 fledglings/breeding pair. Similarly, based on river discharge/fledging success relationship during 2001-2010, the predicted value for colony fledging success in 2011 was 0.41 fledglings/breeding pair, while there were no fledglings produced during the 2011 


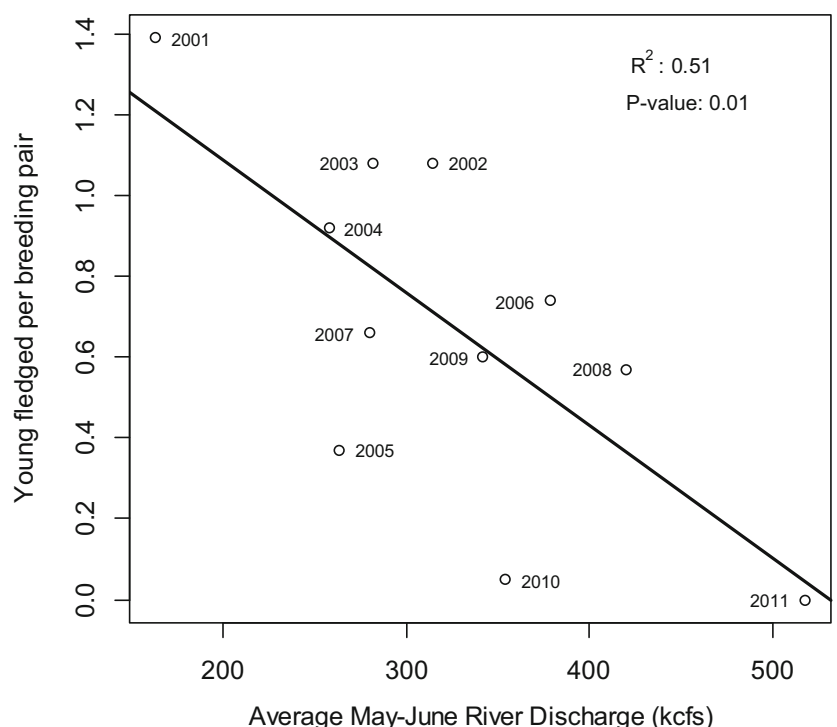

Fig. 2 Annual fledging success (average number of young fledged per breeding pair) of the Caspian tern breeding colony on East Sand Island in the Columbia River estuary as a function of combined average discharge of the Columbia River (thousands of cubic feet per second) in May and June during 2001-2011 $\left(R^{2}=0.51, \mathrm{df}=9, P=0.01\right)$

breeding season. Thus, the very low fledging success experienced at the ESI colony in 2010 and 2011 could not be explained by high river discharge alone.

\section{Food Supply}

\section{Diet Composition}

There was little interannual variation in the taxonomic composition of the diet of Caspian terns nesting on ESI during 2001-2011 (Fig. 3), except for a steady decline in the proportion of clupeids (Pacific herring [C. pallasi], Pacific sardine [S. sagax], and American shad [A. sapidissima]) in the diet and a corresponding increase in the proportion of salmonids (Oncorhynchus spp.) in the diet. The inverse relationship between consumption of salmonids and clupeids was highly significant $\left(R^{2}=0.57, \mathrm{df}=9, P=0.01 ;\right.$ Fig. 4$)$ and did not exist between any other two families of fish prey in the Caspian tern diet. The average percent clupeids in the tern diet during 2001-2009 was 17\%, whereas in 2010 and 2011, clupeids made up 9 and $6 \%$ of tern diets, respectively. The decline in average proportion of clupeids in the diet as a function of year was also highly significant $\left(R^{2}=0.60, \mathrm{df}=9\right.$, $P=0.01)$. Finally, there was a highly significant positive correlation $\left(R^{2}=0.54, \mathrm{df}=9, P=0.01\right)$ between average annual fledging success of Caspian terns at ESI and percent clupeids in the diet during 2001-2011.

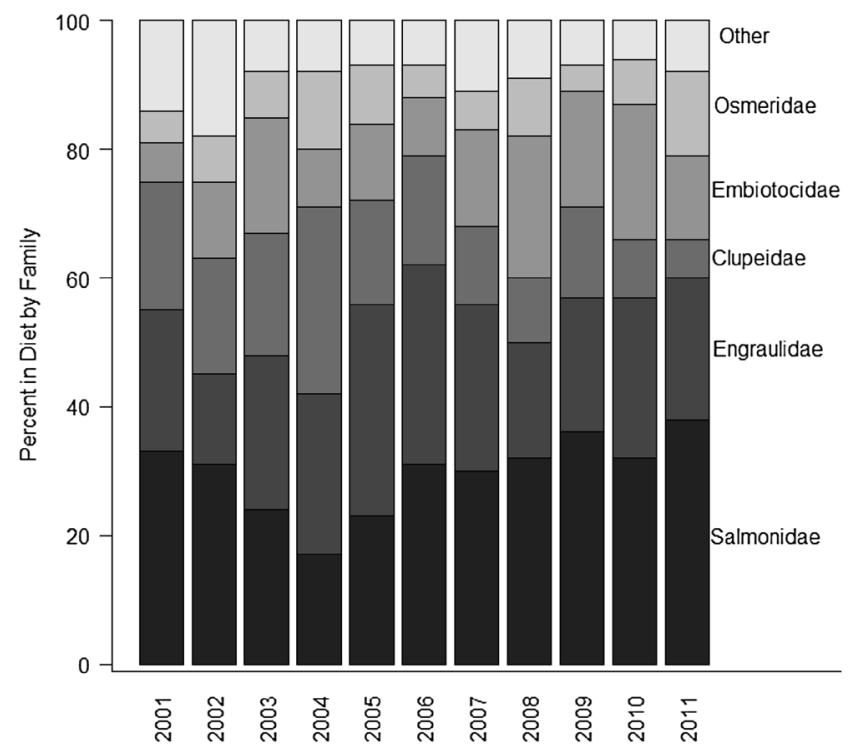

Fig. 3 Percent composition (based on numbers of prey items) of the Caspian tern diet for each year during the study period, 2001-2011. Dominant prey types are identified to family

Prey Availability

In April-June, the combined average CPUE (no. individuals/ $1000 \mathrm{~m}^{2}$ round haul) was 1940.9 in $2007,337.5$ in 2008 , 272.1 in $2009,321.3$ in 2010, and 163.1 in 2011. The highest CPUE occurred in 2007 and was an order of magnitude higher than the lowest CPUE, which occurred in 2011. These disparities in forage fish abundance correspond to the years of lowest (2007) and highest (2011) river discharge during the sampling period. Years with "normal" river discharge (2007,

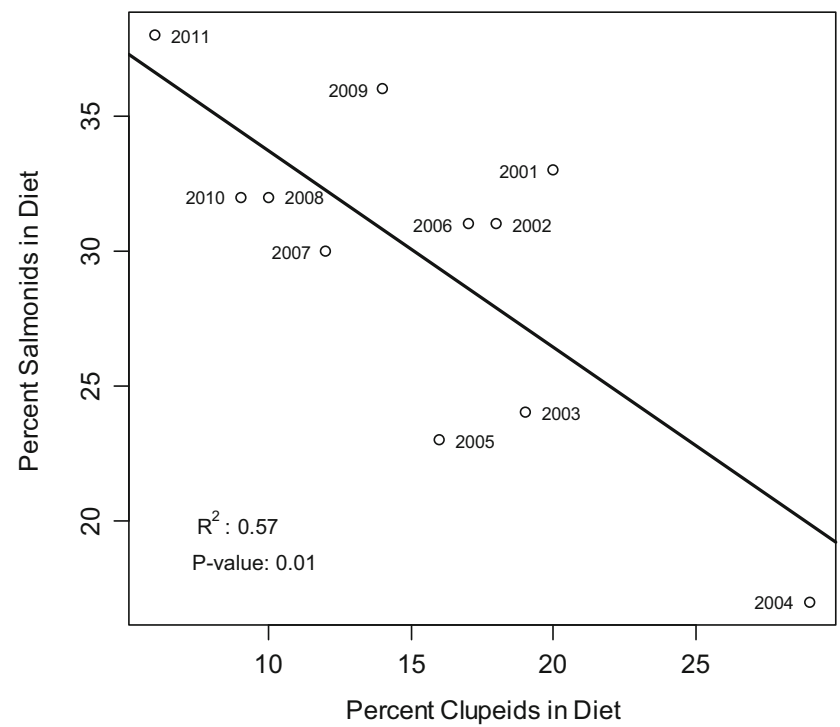

Fig. 4 Average proportion of juvenile salmonids (Oncorhynchus spp., primarily steelhead, coho, and chinook) in the diet as a function of the average proportion of clupeids (American shad, Pacific herring, and Pacific sardine) in the diet for Caspian terns nesting at East Sand Island in the Columbia River estuary during 2001-2011 $\left(R^{2}=0.57, \mathrm{df}=9\right.$, $P=0.01)$ 
2009) were years when CPUE increased from April to June, while years with relatively high river discharge $(2008,2010$, 2011) were years of lower CPUE in April, a peak in CPUE during May, followed by a decline in CPUE during June.

Fish species recorded in trawls and representative of prey found in the diet of Caspian terns included northern anchovy (Engraulis mordax), Pacific herring, shiner perch (Cymatogaster aggregata), surf smelt (Hypomesus pretiosus), American shad, and juvenile salmonids.

\section{Predators}

\section{Eagle Disturbance}

The rate of bald eagle disturbance to the Caspian tern colony on ESI (disturbances/hour of colony observation) exhibited a general seasonal trend across years, with the disturbance rate tending to be high in May and declining as the breeding season progressed. Eagle disturbance rates at the tern colony during May increased from 2004 to 2008 but decreased from 2008 to 2011. In June, however, the frequency of eagle disturbances to the tern colony increased significantly from 2004 to $2011\left(R^{2}=0.53, \mathrm{df}=6, P=0.04\right.$; Fig. 5). There were no significant correlations between the rate of eagle disturbance to the tern colony and fledging success of the tern colony. There was a highly significant positive relationship between river discharge in May and eagle disturbance rate in June during 2004-2011 $\left(R^{2}=0.90, \mathrm{df}=6, P<0.001\right.$; Fig. 6).

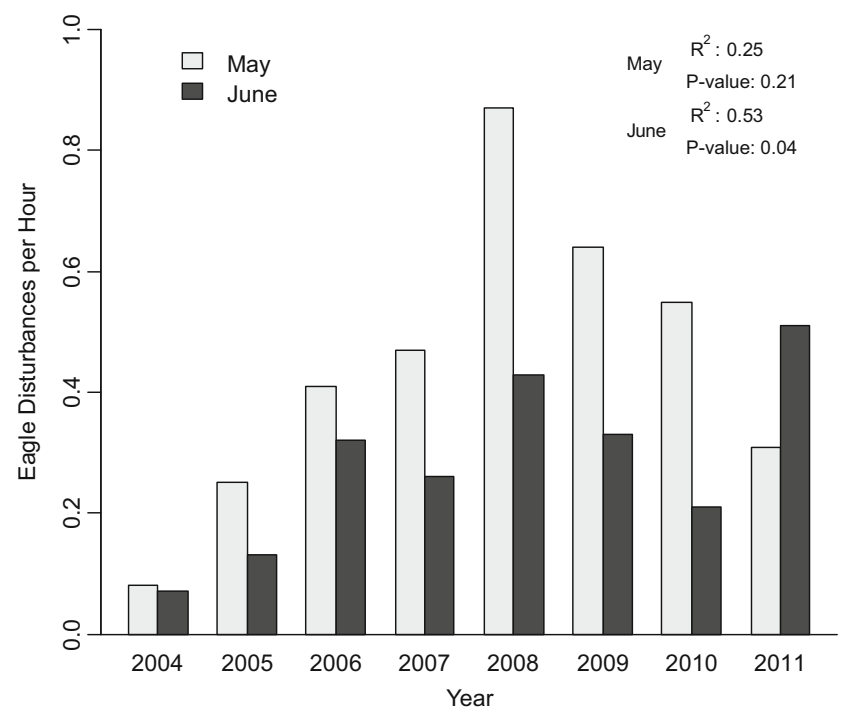

Fig. 5 Rate of bald eagle disturbance events (average number per hour of observation) at the Caspian tern breeding colony on East Sand Island in the Columbia River estuary during May and June of 2004-2011 $\left(R^{2}=0.25, \mathrm{df}=6, P=0.21 ; R^{2}=0.53, \mathrm{df}=6, P=0.04\right)$

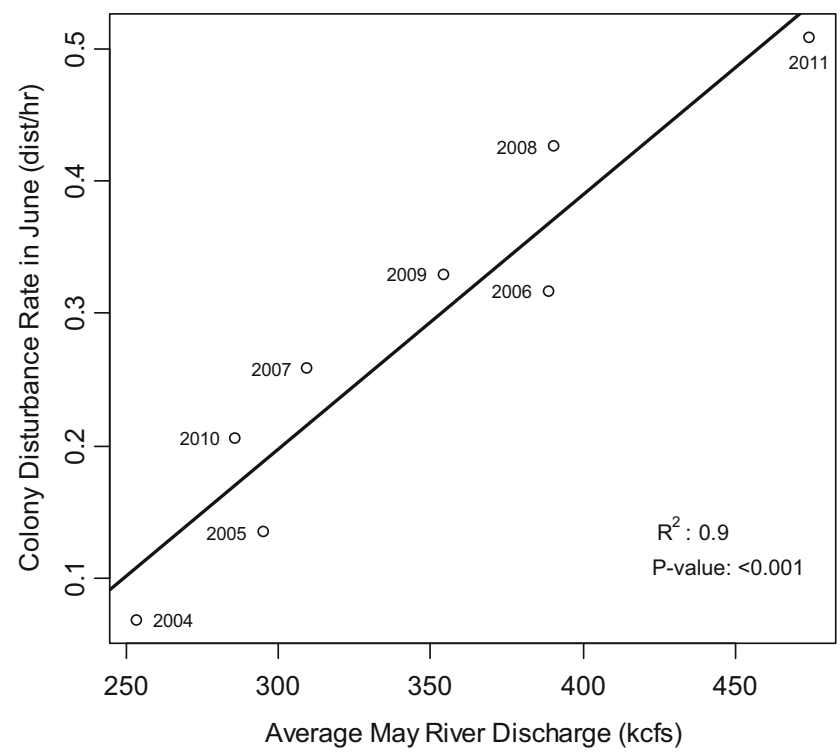

Fig. 6 Rate of bald eagle disturbance events (average number per hour of observation) at the Caspian tern colony on East Sand Island in the Columbia River estuary during June, as a function of average river discharge (kcfs) during May for the period 2004-2011 $\left(R^{2}=0.90\right.$, $\mathrm{df}=6, P<0.001)$

\section{Counts of Breeding Gulls on ESI}

Counts of breeding western gulls and hybrid glaucouswinged/western gulls averaged 7714 breeding individuals, with a minimum of 5496 individuals in 1998 and a maximum of 12,066 individuals in 2001. Data are available on the numbers of breeding gulls at ESI for the 5 years preceding our study period (1996-2000), the first year of our study (2001), the midpoint of our study (2006), and the final 3 years of our study (2009-2011). Counts of western and hybrid gulls breeding on ESI were 1996, 6775; 1997, 7106; 1998, 5496; 1999, 7791; 2000, 9523; 2001, 12,066; 2006, 8587; 2009, 6172; 2010, 6966; and 2011, 6776. Limited removal of predatory gulls nesting on ESI occurred during the first 2 years of colony establishment, totaling 183 gulls removed in 1999 (2\% of breeding individuals) and 40 gulls removed in $2000(<1 \%$ of breeding individuals). The highest fledgling success for Caspian terns during our study period was in 2001 (1.39 fl/ pair), also the year with the highest count of gulls breeding on ESI, but a year in which no lethal gull control was performed. Lethal control was not continued in 2001 because of the high rate of tern fledging success in 2000.

\section{Gull Predation on Tern Nest Contents}

The rate of predation by western gulls and hybrid glaucouswinged/western gulls on the contents of Caspian tern nests at the ESI colony was generally higher in May than in June. The median gull predation rate during 2007-2009 was 0.29 events/h in May and 0.19 events/h in June. During the 2010 
nesting season, this pattern changed, with the gull predation rate averaging 0.22 events/h in May and 0.79 events/h in June; the latter rate is far in excess of the longer term average. During the 2011 nesting season, the gull predation rate averaged 0.51 events/h in May, considerably higher than the longer term average for May. There were no data collected on gull predation rates during June 2011 because all Caspian tern nests on the ESI colony had been depredated by the first week of June. In most years, nest depredation by gulls was the result of a limited number of specialist individuals nesting on the periphery of the colony.

\section{Kleptoparasitism by Gulls}

There was a significant negative correlation between the observed average annual rate of gull kleptoparasitism and fledging success at the ESI Caspian tern colony during 2001-2011 $\left(R^{2}=0.38, \mathrm{df}=9, P=0.04\right)$. There was a significant increase in rates of gull kleptoparasitism from 2001 to $2011\left(R^{2}=0.52\right.$, df $=9, P=0.01 ;$ Fig. 7). There was a significant positive relationship between observed average annual rate of gull kleptoparistism and average combined river volume for May and June 2001-2011 $\left(R^{2}=0.52, \mathrm{df}=9, P=0.01\right.$; Fig. 8). The average gull kleptoparasitism rate during 2001-2009 was 0.05 fish kleptoparasitized/bill-load fish monitored; in both 2010 and 2011, the kleptoparasitism rate averaged 0.08 fish kleptoparasitized/bill-load fish.

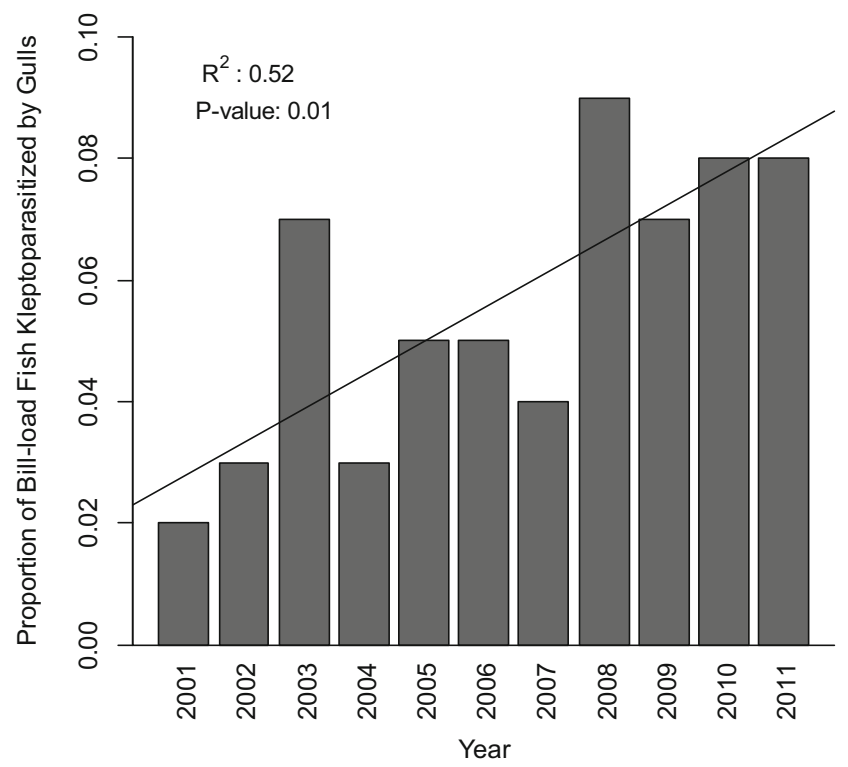

Fig. 7 Proportion of fish being transported by adult Caspian terns to the breeding colony on East Sand Island in the Columbia River estuary that were kleptoparasitized by western gulls and hybrid glaucous-winged/ western gulls as a function of year during 2001-2011 $\left(R^{2}=0.52\right.$, $\mathrm{df}=9, P=0.01)$

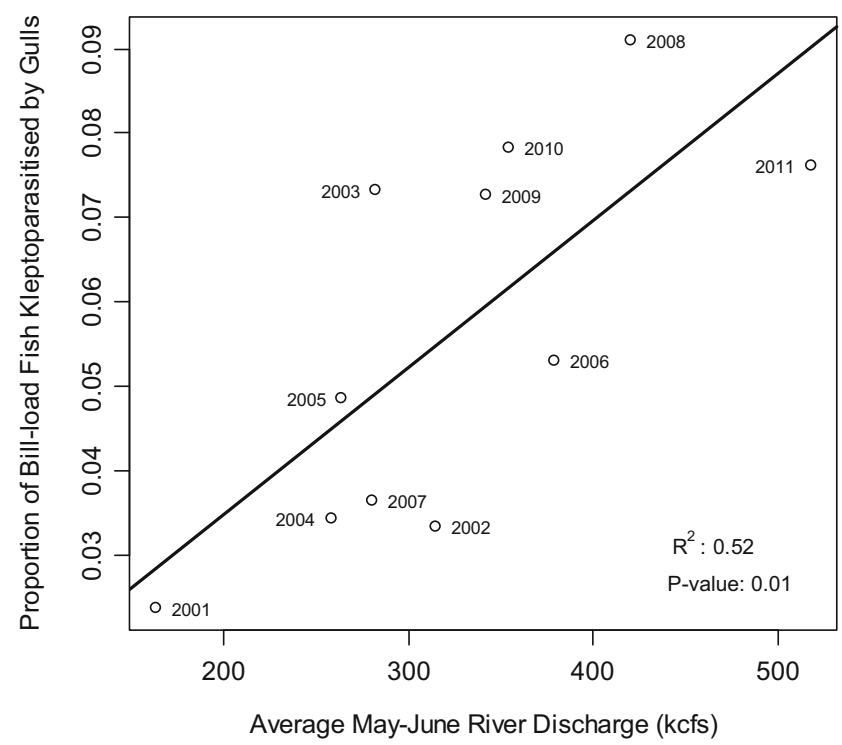

Fig. 8 Proportion of fish being transported by adult Caspian terns to the breeding colony on East Sand Island in the Columbia River estuary that were kleptoparasitized by western gulls and hybrid glaucous-winged/ western gulls as a function of average combined river volume (kcfs) in May and June 2001-2011 $\left(R^{2}=0.52, \mathrm{df}=9, P=0.01\right)$

\section{Model Selection}

After exploring the relationship of each explanatory variable with the response variable "average annual fledging success" independently and assessing the correlations among all explanatory variables (Table 1), we created a set of a priori additive models to compare the predictive power of models containing a single explanatory variable to models containing multiple explanatory variables. Because of the highly significant positive correlation between river discharge in May and river discharge in June, a single variable combining the average flow rate during May and June was used in model selection (Table 2). When ranked using $\triangle \mathrm{AICc}$ scores, the model that best fit the data contained only the explanatory variable "river volume during May and June" and had a model weight of $0.52\left(R^{2}=0.51, P=0.01\right.$; Table 2$)$. No other candidate model was competitive with this top model $(\triangle \mathrm{AICc}<2.0)$.

\section{Discussion}

We found that the declining fledging success experienced by Caspian terns nesting at the ESI colony during 2001-2011 was associated with the interactions of top-down and bottom-up processes. A consistent and key explanatory variable for the variation in fledging success was the increasing volume of the Columbia River during the breeding seasons encompassed by the study period. There was an inverse correlation between average river discharge during the nesting season and average annual fledging success at the ESI colony. This relationship may be a proxy for declining abundance and 
Table 1 Pearson's correlation matrix showing the correlations between selected explanatory variables used in the analysis of potential factors explaining variation in average fledging success of Caspian terns at the East Sand Island colony

\begin{tabular}{|c|c|c|c|c|c|}
\hline & $\begin{array}{l}\text { Fledging } \\
\text { success }\end{array}$ & $\begin{array}{l}\text { June river } \\
\text { discharge }\end{array}$ & $\begin{array}{l}\text { Kleptoparasitism } \\
\text { rate }\end{array}$ & $\begin{array}{l}\text { May } \\
\text { disturbance } \\
\text { rate }\end{array}$ & $\begin{array}{l}\text { June } \\
\text { disturbance } \\
\text { rate }\end{array}$ \\
\hline \multirow{2}{*}{$\begin{array}{l}\text { June river } \\
\text { discharge }\end{array}$} & -0.7 & - & - & - & - \\
\hline & 0.02 & - & - & - & - \\
\hline \multirow{2}{*}{$\begin{array}{l}\text { Kleptoparasitism } \\
\text { rate }\end{array}$} & -0.62 & 0.7 & - & - & - \\
\hline & 0.04 & 0.02 & - & - & - \\
\hline \multirow{2}{*}{$\begin{array}{l}\text { May disturbance } \\
\text { rate }\end{array}$} & -0.12 & 0.36 & 0.74 & - & - \\
\hline & 0.78 & 0.38 & 0.04 & - & - \\
\hline \multirow{2}{*}{$\begin{array}{l}\text { June disturbance } \\
\text { rate }\end{array}$} & -0.39 & 0.81 & 0.69 & 0.55 & - \\
\hline & 0.34 & 0.01 & 0.06 & 0.16 & - \\
\hline \multirow{2}{*}{$\begin{array}{l}\text { May river } \\
\text { discharge }\end{array}$} & -0.66 & 0.83 & 0.68 & 0.31 & 0.95 \\
\hline & 0.03 & 0.002 & 0.02 & 0.46 & 0.0003 \\
\hline
\end{tabular}

The top number is the Pearson's correlation coefficient; the bottom number is the $P$ value, representing the significance of the correlation for each pair of explanatory variables. Values in italics represent those correlations significant at the $\alpha=0.05$ level accessibility of forage fish prey for both the terns and other generalist avian species in the estuary. Also, the increase in predatory gull activities focused on the tern colony, particularly nest depredation that occurred during colony disturbances by bald eagles, was associated with increasing river discharge, which indicates the link between the effects of bottom-up and top-down factors on fledging success at our study site. Decreasing availability of forage fish is likely responsible for prey switching in both gulls and bald eagles, leading to increased top-down pressure on the tern colony. Suryan et al. (2006) found that the influence of top-down or bottom-up forces on seabird colonies in Prince William Sound, Alaska, oscillated depending on physical processes governing the phytoplankton bloom. Similarly, at the ESI Caspian tern colony, the primary physical process that influenced bottom-up and top-down effects on tern fledging success appeared to be river discharge during the breeding season.

Increased freshwater input can affect the recruitment, residence time, and location of fishes in an estuary, as well as altering fish assemblages and abundance, especially of marine forage fishes (Jassby et al. 1995; Loneragan and Bunn 1999; Purtlebaugh and Allen 2010). Weitkamp et al. (2012) found reduced fish abundance and altered species representation in 2008, 2010, and 2011, years of unusually high discharge for the Columbia River, and reported that these "natural experiments for the influence of flow" resulted in both a decrease in numbers of marine forage fishes, especially northern anchovy and Pacific herring, and a decrease in residence time for juvenile salmonids. High river flow events may physically and physiologically exclude marine-adapted fishes from the estuary, and species that move into the estuary from the ocean seasonally may be inhibited due to the unusually low salinity, high volume of discharge, and accompanying high flows (Lyons 2010). The decline in salinity associated with large volumes of freshwater moving through the estuary can create less hospitable environments for fishes adapted to a primarily marine environment (Jassby et al. 1995). In 2007, a year of normal river discharge, surf smelt, Pacific herring, American shad, and northern anchovy, which are all euryhaline marine forage fishes, made up 54\% of fishes sampled by Weitkamp
Table 2 The top five linear models selected from the set of models based on a priori hypotheses of the factors affecting productivity of the Caspian tern colony on East Sand Island in the Columbia River estuary

\begin{tabular}{clccc}
\hline Rank & Model $^{\mathrm{a}}$ & AICc & $\Delta$ AICc & $W_{i}$ \\
\hline 1 & Avg. river discharge in May and June & 11.1 & 0.0 & 0.52 \\
2 & Avg. river discharge in May and June + avg. annual kleptoparasitism rate & 13.6 & 2.5 & 0.15 \\
3 & Avg. annual kleptoparasitism rate & 13.7 & 2.6 & 0.14 \\
4 & Avg. river discharge in May and June + maximum rainfall in 48 h & 13.7 & 2.6 & 0.14 \\
5 & Avg. annual kleptoparasitism rate + maximum rainfall in 48 h & 16.1 & 5.0 & 0.04 \\
\hline
\end{tabular}

No models included in the model set included explanatory variables that were significantly correlated $(\alpha=0.05)$. Models are ranked in ascending order based on $\triangle \mathrm{AICc}$ score. The $\triangle \mathrm{AICc}$ score is calculated by subtracting each model's AICc score from the lowest AICc score, i.e., the model best supported by the available data

${ }^{\text {a }}$ Variables included in model selection: (1) average river discharge in May and June, (2) average annual kleptoparasitism rate, and (3) maximum rainfall in $48 \mathrm{~h}$

${ }^{\mathrm{b}}$ The model best supported by the data and the only competitive candidate model among the model set 
et al. (2012), while in 2011, the most extreme year of high river discharge, these marine forage fishes accounted for only $27 \%$ of fishes sampled.

Weitkamp et al. (2012) found that salinity measured at depths of $7 \mathrm{~m}$ in the Columbia River estuary was more predictably affected by tide than river discharge but that salinities measured at a depth of $1 \mathrm{~m}$ were most sensitive to discharge, with the lowest maximum salinity during flows $\geq 11.0 \mathrm{~m}^{3} / \mathrm{s}$. This threshold for discharge was exceeded during most sampling dates in 2008 and during the final two trawl samples collected in 2010, with discharge averaging 12.8 and $12.5 \mathrm{~m}^{3} / \mathrm{s}$, respectively; discharge throughout April-June 2011 was higher still. Weitkamp et al. (2012) suggested that these high flow events led to water column stratification and the presence of a "freshwater lens" of approximately 1-m depth in the Columbia River estuary. This stratification would lead to further segregation of marine-adapted and freshwater-adapted fishes, putting the already reduced number of marine forage fish present in the estuary out of reach of avian predators that forage in the top $1 \mathrm{~m}$ of the water column, such as Caspian terns, western and hybrid gulls, and bald eagles.

Interannual variation in abundance of salmonids in the estuary is minimized through hatchery supplementation; approximately 140 million smolts were released annually from Columbia River hatcheries during 2007-2010. Nevertheless, juvenile salmonids made up $<5 \%$ of the total number of fish caught per trawl (Weitkamp et al. 2012). This low fraction of salmonids takes on special significance in years when extremely high river discharge excludes most marine forage fish from the estuary, leaving juvenile salmonids to dominate the forage fish community in estuary waters and resulting in a severely reduced overall prey abundance near the surface. This is supported by the disparate CPUE totals for 2011 $\left(163 \mathrm{fish} / 1000 \mathrm{~m}^{2}\right)$, the year of greatest river discharge, compared to $2007\left(1941 \mathrm{fish} / 1000 \mathrm{~m}^{2}\right)$, the year of lowest river discharge during the study period.

Also, higher than average river volume can decrease the estuary residence time of juvenile salmonid species migrating to the ocean. In normal flow years $(2007,2009)$, juvenile salmonids (primarily steelhead [O. mykiss], coho salmon [O. kisutch], and Chinook salmon [O. tshawytscha]) had variable peaks in abundance and were prevalent within the estuary for 6-8 weeks. During the relatively high flow conditions in 2008, salmonid out-migration was concentrated into a single peak, which was recorded during the 20 May sampling effort, with lower than average catch rates for trawls occurring after 20 May (Weitkamp et al. 2012). During May and June 2011, Columbia River discharge exceeded flows recorded in 2008 by over $100 \mathrm{kcfs}$ each month. It is likely that the abbreviated period of salmonid out-migration that was evident in 2008 was even more pronounced in 2011.

There is a demonstrated link between prey availability and reproductive output in seabirds (Hall and Kress 2004; Votier et al. 2009; Satterthwaite et al. 2012). Fledging success is affected both directly and indirectly by poor foraging conditions; food availability can directly affect adult and chick survival, and low prey availability can lead to longer distance adult foraging trips, longer foraging trip duration, lower adult nest attendance, and, ultimately, higher nest abandonment rates (Anderson et al. 2005). Lower adult nest attendance can also result in periods when neither parent is present at the nest, leaving eggs and chicks unprotected and vulnerable to predation at the nest (Coulson and Thomas 1985; Roberts and Hatch 1993; Finney et al. 1999). Even with the increased accessibility to juvenile salmonids resulting from enhanced water column stratification, the drastic reduction in available forage fish prey in years of extremely high river discharge likely affects not only breeding Caspian terns but also all piscivorous predators in the estuary.

ESI is home to a sizable breeding colony of western gulls and hybrid glaucous-winged/western gulls (ca. 8000 breeding pairs), some of which specialize in kleptoparasitism of Caspian terns and predation on Caspian tern nest contents. These gulls can be highly aggressive and may use their size advantage to steal fish being transported back to the colony by terns and to displace terns from their nest scrapes, consuming both eggs and chicks (SC, pers. obs.). Although kleptoparasitism is widespread among animal taxa (Morand-Ferron et al. 2007), it is a behavior most often employed opportunistically or at times when food availability is low (Flower et al. 2013). Recent studies suggest that animals will kleptoparasitize over other foraging behaviors when kleptoparasitism opens up otherwise unattainable foraging niches (Flower et al. 2013). As river discharge increases, prey availability for gulls would become more severely limited than for Caspian terns, which are better able to capture fish prey compared to gulls. In years of limited forage, it would be adaptive for gulls to put more energy into stealing high-value prey items, which is what we observed at our study site (Fig. 8). Despite the increase in kleptoparasitism and nest depredation, there were $~ 5000$ fewer gulls breeding on ESI at the end of our study period than at the colony's inception. The highest fledging success numbers for Caspian terns at this colony occurred in 2001, the first year of our study, coincident with the highest number of breeding gulls (12066) and the lowest measured river volume (476.9 kcfs). The decadal increase in kleptoparasitism rate, combined with the positive relationship between kleptoparasitism and river volume, likely reflects the increasing reliance of particular gull individuals on this behavior in years of poor foraging opportunities (functional response), rather than an increase in the overall gull population on the island (numerical response).

We found a compelling link between prey availability as regulated by river volume and depredation of the tern colony by gulls and bald eagles. As river volume increased between 2001 and 2011, we recorded increased rates of colony disturbance by bald eagles, leading to increased rates of tern nest depredation by gulls. At our study colony, bald eagles were 
routinely seen harassing Caspian terns and kleptoparasitising their bill loads (SC, pers. obs.), but in 2011, adult terns on the colony were targeted as prey by bald eagles. Bald eagles are not new to East Sand Island and likely were common there before Caspian terns began to nest on the island in 1999 (Watson et al. 1991). Nevertheless, the prolonged period of targeted predation on nesting Caspian terns that occurred on East Sand Island in 2011 was unprecedented for this colony.

Notably, the average river discharge in May was an excellent predictor of the rate of disturbance the tern colony experienced in June. While this time lag may seem counter-intuitive, it makes sense when prey abundance and accessibility are influenced by river discharge, as they are so prominently in this estuary. The frequency, magnitude, timing, and duration of colony disturbance events are important limiting factors because they facilitate nest predation events that can have a profound impact on colony fledging success (Hipfner et al. 2012; White et al. 2006). At our study site, there was an inverse relationship between river discharge and the abundance and accessibility of prey. Especially high river discharge in May likely contributed to chronic food stress, not only for nesting terns but also for other piscivorous birds in the estuary. In this manner, high river discharge in May could result in a tern colony that is subsequently under pressure from predators and predators that were more likely to switch from preying on fish to preying on tern chicks and adults. Poor prey resources severely limit a breeding individual's ability to feed itself, its mate, or its young, and limited prey resources may cause breeding birds to allocate more of their time toward obtaining sufficient prey to meet their own maintenance requirements and less time or effort on requirements for successful reproduction (Coulson and Thomas 1985; Roberts and Hatch 1993). Additionally, in 2008, 2010, and 2011, river discharge continued to increase through June, further limiting the ability of piscivorous birds in the Columbia River estuary to rely on fish prey to adequately provision themselves and any offspring. These 3 years were also those with the highest peak river discharge and the lowest fledging success at the ESI Caspian tern colony during the study period. Bald eagle disturbance events during May and June of 2011 played a prominent role in the subsequent failure of all Caspian tern nesting attempts at the ESI colony during the 2011 breeding season. This same association between increased bald eagle disturbance and higher predation rates on nest contents of colonial seabirds has been documented at a number of other breeding colonies and, in some cases, has been linked to subsequent colony failure (Verbeek 1982; Parrish et al. 2001; Vennesland and Butler 2004).

The number of Caspian tern breeding pairs at ESI changed little over the course of our study despite fluctuating environmental and predation pressures. Caspian terns are generally accepted to have evolved low levels of breeding site fidelity in response to the ephemeral nature of their preferred breeding habitat, i.e., low-lying sand islands (McNicholl 1975;
Southern and Southern 1982; Cuthbert 1985). Band resighting records show a high degree of connectivity between breeding sites for the Caspian tern population on the west coast of the USA (Suzuki 2012); however, Caspian terns in our study showed a tendency to favor ESI over alternative colony sites, even after substantial reductions in available habitat and increased predation (S. Collar, unpublished data). This unexpected degree of site fidelity is likely a result of limited availability of quality breeding sites in the Pacific Northwest. Since 2000, alternative colonies in western Washington have been established in a variety of habitats, including a small dredge spoil island (Padilla Bay, WA), a gravel spit (Dungeness Spit NWR, WA), an abandoned parking lot (Bellingham, WA), and several warehouse roofs at the Kitsap-Bremerton Naval Base, WA, and in Seattle, WA. While several of these colonies successfully fledged chicks in one or more years, all were eventually abandoned due to predation (mammalian and avian) or active dissuasion. Similarly, Caspian tern colonies in eastern Washington and Oregon have been increasingly unsuccessful, as a result of dissuasion implemented by managers, avian and mammalian predation, and an insufficient prey base (Patterson 2012; Collis et al. 2015).

\section{Conclusions}

Our results, although correlative, suggest that interactions between bottom-up and top-down regulating factors, driven largely by variable freshwater input to the Columbia River estuary, limited Caspian tern fledging success at the large breeding colony on East Sand Island. We found that river discharge was highly negatively correlated to fledging success at this colony. Fledging success of the tern colony has declined as freshwater input during the tern breeding season has increased. Recent higher than average river discharge led to declines in the abundance and availability to terns of marine forage fishes in the estuary, which, in turn, limited food availability to many estuary consumers. The decline in prey availability likely contributed to the increase in bald eagle disturbance and gull kleptoparasitism at the Caspian tern colony and to the corresponding increase in depredation rates on tern nests by gulls due to the synergistic impact of eagle disturbance and gull predation on tern fledging success.

Acknowledgments We thank Dr. L.A. Weitkamp with NOAA Fisheries, Northwest Fisheries Science Center for providing data and expertise regarding the Columbia River estuary fish community. We are grateful to M. Koberstein, B. Cramer, T. Marcella, A. Peck-Richardson, and $\mathrm{K}$. Courtot for valuable assistance in the field and the US Army Corps of Engineers, Portland District, Portland, OR, for granting permission to access East Sand Island to conduct this study. Funding was provided by the Bonneville Power Administration, Portland, OR (Dorothy Welch). All animal handling protocols were approved by the Oregon State University Institutional Animal Care and Use Committee. We thank J.Y. Adkins, L.J. Adrean, J.R. Lovvorn, and two anonymous reviewers for insightful comments that improved earlier drafts of this manuscript. 
Open Access This article is distributed under the terms of the Creative Commons Attribution 4.0 International License (http:// creativecommons.org/licenses/by/4.0/), which permits unrestricted use, distribution, and reproduction in any medium, provided you give appropriate credit to the original author(s) and the source, provide a link to the Creative Commons license, and indicate if changes were made.

\section{References}

Anderson, S.K., D.D. Roby, D.E. Lyons, and K. Collis. 2005. Factors affecting chick provisioning by Caspian terns nesting in the Columbia River estuary. Waterbirds 28: 95-105.

Collis, K., D.D. Roby, D.P. Craig, S. Adamany, J.Y. Adkins, and D.E. Lyons. 2002. Colony size and diet composition of piscivorous waterbirds on the lower Columbia River: implications for loses of juvenile salmonids to avian predation. Transactions of the American Fisheries Society 131: 537-550.

Collis, K., D.D. Roby, C. Baird, T. Lawes, A. Wilson, C. Congdon, and A.F. Evans. 2015. Monitoring and Predator Control at the CorpsConstructed Caspian Tern Islands in Southeastern Oregon and Northeastern California, 2015. Unpublished annual report. November 30, 2015. Available at: http://www.birdresearchnw.org/ 2015\%20Predator\%20Control\%20Final\%20Report_v12.pdf

Coulson, J.C., and J.C. Thomas. 1985. Changes in the biology of the kittiwake Rissa tridactyla: A 31-year study of a breeding colony. Journal of Animal Ecology 54: 9-26.

Cuthbert, F.J. 1985. Intraseasonal movement between colony sites by Caspian terns in the Great Lakes. Wilson Bulletin 97: 502-510.

Finney, S.K., S. Wanless, and M.P. Harris. 1999. The effect of weather conditions on the feeding behaviour of a diving bird, the common guillemot Uria aalge. Journal of Avian Biology 30: 23-30.

Flower, T.P., M.F. Child, and A.R. Ridley. 2013. The ecological economics of kleptoparasitism: pay-offs from self-foraging versus kleptoparasitism. Journal of Animal Ecology 82: 245-255.

Gripenberg, S., and T. Roslin. 2007. Up or down in space? Uniting the bottom-up versus top-down paradigm and spatial ecology. Oikos 116: 181-188.

Hall, C.S., and S.W. Kress. 2004. Comparison of common tern reproductive performance at four restored colonies along the Maine coast, 1991-2002. Waterbirds 27: 424-433.

Harvey, C.J., G.D. Williams, and P.S. Levin. 2012. Food web structure and trophic control in central Puget Sound. Estuaries and Coasts 35: $821-838$.

Hipfner, J.M., L.K. Blight, R.W. Lowe, S.I.R. Wilhelm, G.J. Robertson, R.T. Barrett, T. Anker-Nilssen, and T.P. Good. 2012. Unintended consequences: How the recovery of sea eagle Haliaeetus spp. populations in the northern hemisphere is affecting seabirds. Marine Ornithology 40: 39-52.

Hunt, G.L. Jr., and S. McKinnell. 2006. Interplay between top-down, bottom-up and wasp-waist control in marine ecosystems. Progress in Oceanography 68: 115-124.

Hunter, M.D., and P.W. Price. 1992. Playing chutes and ladders: Heterogeneity and the relative role of bottom-up and top-down forces in natural communities. Ecology 73: 724-732.

Isaacs, F.B., and R.G. Anthony. 2011. Bald eagles (Haliaeetus leucocephalus) nesting in Oregon and along the lower Columbia River, 1978-2007. Final Report, 18 March 2011. Oregon Cooperative Fish and Wildlife Research Unit, Department of Fisheries and Wildlife, Oregon State University, Corvallis.

Jassby, A.D., W.J. Kimmerer, S.J. Monismith, C. Armor, J.E. Cloern, T.M. Powell, J.R. Schubel, and T.J. Vendlinski. 1995. Isohaline position as a habitat indicator for estuarine populations. Ecological Applications 5: 272-289.
Loneragan, N.R., and S.E. Bunn. 1999. River flows and estuarine ecosystems: Implications for coastal fisheries from a review and a case study of the Logan River, southeast Queensland. Australian Journal of Ecology 24: 431-440.

Lyons, D.E. 2010. Bioenergetics-based predator-prey relationships between piscivorous birds and juvenile salmonids in the Columbia River estuary. Unpubl. Ph.D. dissertation, Oregon State University, Corvallis. 310 p. Available at: http://www.birdresearchnw.org/ CEDocuments/Downloads_GetFile.aspx $?$ id $=393826 \& f d=0$

McNicholl, M.K. 1975. Larid site tenacity and group adherence in relation to habitat. Auk 92: 98-104.

Morand-Ferron, J., D. Sol, and L. Lefebvre. 2007. Food stealing in birds: brain or brawn? Animal Behaviour 74: 1725-1734.

Munch, S.B., M.L. Snover, G.M. Watters, and M. Mangel. 2005. A unified treatment of top-down and bottom-up control of reproduction in populations. Ecology Letters 8: 691-695.

Parrish, J.K., M. Marvier, and R.T. Paine. 2001. Direct and indirect effects: Interactions between bald eagles and common murres. Ecological Applications 11: 1858-1869.

Patterson, A., 2012. Breeding and Foraging Ecology of Caspian Terns Nesting on Artificial Islands in the Upper Klamath Basin, California. Unpubl. Master's thesis, Oregon State University, Corvallis.

Purtlebaugh, C.H., and M.S. Allen. 2010. Relative abundance, growth and mortality of five age- 0 estuarine fishes in relation to discharge of the Suwanee River, Florida. Transactions of the American Fisheries Society 139: 1233-1246.

R Development Core Team. 2011. R: A language and environment for statistical computing. Vienna: R Foundation for Statistical Computing URL http://www.R-project.org/.

Roberts, B.D., and S.A. Hatch. 1993. Behavioral ecology of black-legged kittiwakes during chick rearing in a failing colony. Condor 95: 330342.

Satterthwaite, W.H., A.S. Kitaysky, and M. Mangel. 2012. Linking climate variability, productivity and stress to demography in a longlived seabird. Marine Ecology Progress Series 454: 221-235.

Southern, W.E., and L.K. Southern. 1982. Effect of habitat decimation on a ring-billed gull colony and nest site tenacity. Auk 99: 328-331.

Suryan, R.M., D.B. Irons, E.D. Brown, P.G.R. Jodice, and D.D. Roby. 2006. Site-specific effects on productivity of an upper trophic-level marine predator: Bottom-up, top-down and mismatch effects on reproduction in a colonial seabird. Progress in Oceanography 68: 303-328.

Suzuki, Y., 2012. Piscivorous Colonial Waterbirds in the Columbia River Estuary: Demography, Dietary Contaminants, and Management. Unpubl. Ph.D Dissertation, Oregon State University, Corvallis.

Vennesland, R.G., and R.W. Butler. 2004. Factors influencing great blue heron nesting productivity on the Pacific coast of Canada from 1998 to 1999. Waterbirds 27: 289-296.

Verbeek, N.A. 1982. Egg predation by northwestern crows: Its association with human and bald eagle activity. Auk 99: 347-352.

Votier, S.C., B.J. Hatchwell, M. Mears, and T.R. Birkhead. 2009. Changes in the timing of egg-laying of a colonial seabird in relation to population size and environmental conditions. Marine Ecology Progress Series 393: 225-233.

Watson, J.W., M.G. Garrett, and R.G. Anthony. 1991. Foraging ecology of bald eagles in the Columbia River estuary. Journal of Wildlife Management 55: 492-499.

Weitkamp, L.A., P.J. Bentley, and M.N.C. Litz. 2012. Seasonal and interannual variation in juvenile salmonids and associated fish assemblage in open waters of the lower Columbia River estuary. Fisheries Bulletin 110: 426-450.

White, A.F., J.P. Heath, and B. Gisborne. 2006. Seasonal timing of bald eagle attendance and influence on activity budgets of glaucouswinged gulls in Barkley Sound, British Columbia. Waterbirds 29: 497-500. 